\title{
Mini-Grid Hydropower for Rural Electrification in Mozambique: Meeting Local Needs with Supply in a Nexus Approach
}

\author{
Miguel M. Uamusse ${ }^{1,2, *(\mathbb{D})}$, Kamshat Tussupova ${ }^{1,3,4}$, Kenneth M. Persson ${ }^{1}$ and \\ Ronny Berndtsson 1,3 \\ 1 Department of Water Resources Engineering, Lund University, Box 118, SE-221 00 Lund, Sweden; \\ kamshat.tussupova@tvrl.lth.se (K.T.); kenneth.m.persson@tvrl.lth.se (K.M.P.); \\ ronny.berndtsson@tvrl.lth.se (R.B.) \\ 2 Department of Chemical Engineering, University Eduardo Mondlane, Box 257, \\ CP 257 Maputo, Mozambique \\ 3 Center for Middle Eastern Studies, Lund University, Box 201, SE-221 00 Lund, Sweden \\ 4 Center for Transfer of Technology, Karaganda State Medical University, 100004 Karaganda, Kazakhstan \\ * Correspondence: miguel.uamusse@tvrl.lth.se; Tel.: +46-46-222-4538
}

Received: 23 December 2018; Accepted: 10 February 2019; Published: 12 February 2019

\begin{abstract}
UN Sustainable Development Goal (SDG) 7 states that access to affordable, reliable, sustainable, and modern energy should be provided for all by 2030. Mozambique is one of the poorest countries on earth but has abundant supply of energy resources. The electrification rate, however, has been slow. Rural electrification is hampered by lack of basic infrastructure, institutional barriers, and low ability and willingness to pay for energy services. Thus, there is a general gap between electricity supply and demand. In view of this, the present paper investigates supply and demand of electricity for a typical rural case study area in Mozambique. We suggest a nexus approach to improve water, energy, and food security initiated at a local level. Households in the investigated case study area can be connected to a mini-grid hydropower system that allows for energy production to 80-200 households. To increase the economic profitability of the mini-grid hydropower system we suggest including small-scale industry. For the studied rural village, this would be constituted by a small-scale factory for milling of corn and other cereals. Electricity produced can thus be used for food processing but also for pumping water supply to households for domestic use and small-scale irrigated farming lots. The results indicate that the villagers have a real payment capacity of between 8 and 19 USD per MWh of generated hydropower. Benefits of rural electrification are direct. It contributes to improved living conditions for households and provides better nexus security and sustainable development within healthcare, education, and small-scale business development.
\end{abstract}

Keywords: water management; water-food-energy nexus; hydropower; rural electrification; climate change; Mozambique

\section{Introduction}

Access to affordable, reliable, sustainable, and modern energy for all is one of the UN Sustainable Development Goals (SDGs) [1,2]. In total, 1.3 billion people in the world are living without access to electricity and in a state of poverty. Approximately $85 \%$ of these people live in rural areas [3]. The present Mozambican population of about 30 million is rapidly increasing. According to the 2017 national census, at least 20 million people in the country live without access to electricity and in absolute poverty [4]. Approximately $60 \%$ live in rural areas and use biomass as the primary energy source for cooking and heating and kerosene for lighting. This creates health problems for the population and 
environmental problems in terms of deforestation and release of greenhouse gases. Most rural areas in Mozambique cannot be reached by the national grid due to long distances, lacking infrastructure, and very poor population that may not be able to pay for the service. To improve rural conditions and create means of sustainable development, other ways of electrification need to be considered. Using off-grid systems can be a cost-effective option for rapid electrification of rural areas. Off-grid systems that make use of small hydropower plants can be employed with an objective to decentralize power generation through creating autonomous power plants for specific communities [5].

Even though the average annual per capita consumption of electricity in Mozambique is only $\sim 463 \mathrm{kWh}$, Mozambique produces large amounts of energy [6]. In total, 17,000 GWh/year are produced in four main hydropower plants: Corumana (49 GWh/year), Chicamba (89 GWh/year), Mavuzi (238 GWh/year), and Hidroeléctrica de Cahora Bassa (HCB) with a total generation of $\sim 16,000 \mathrm{GWh}$ /year. A great paradox, however, is the fact that more than $70 \%$ of the electricity produced are exported (Figure 1) [5,7,8]. As an example, during 2012, electricity was sold from the HCB to South Africa, Mozambique, Zimbabwe, and Botswana for a price of $3.6 \mathrm{USD} / \mathrm{kWh}$. During the same year, energy was imported at a cost of $30 \mathrm{USD} / \mathrm{kWh}$ [9]. This export/import setup is guaranteed until 2027 by a long-term treaty.

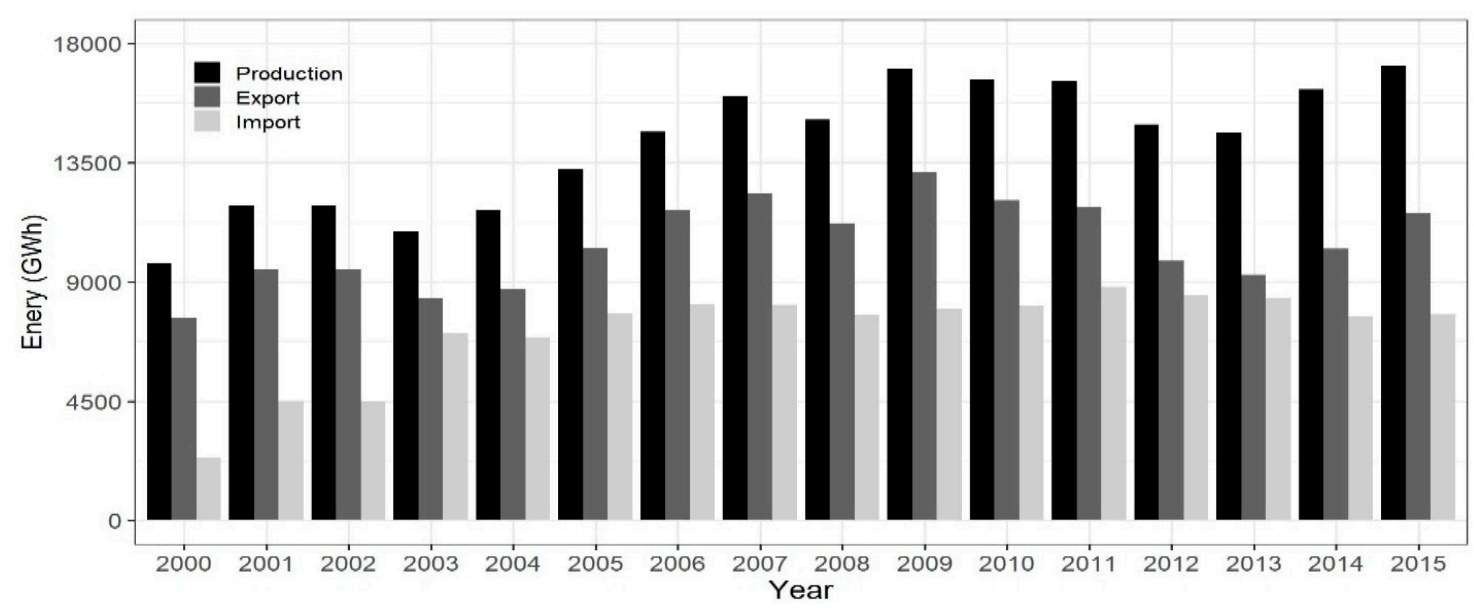

Figure 1. Electricity production and use in Mozambique. Source: own illustration with information from $[5,7,8]$.

As indicated above, mainly large-scale hydropower projects have been realized in Mozambique. These have been prioritized due to the fact that consumers have primarily been industry and export. Other reasons include the lack of capacity to implement small-scale hydropower projects, the lack of clear process, the difficulties to involve private investors, and the lack of focus of the sector $[10,11]$. Medium-sized hydropower plants can be defined as 10-100 MW. Research often defines renewable and sustainable hydropower as less than $10 \mathrm{MW}$ plants because large reservoirs may imply negative environmental impacts [10]. Thus, to supply rural consumers with electricity in a sustainable manner, small-scale hydropower through off-grid or mini-grid solutions may be necessary. Off-grid systems such as small hydropower plants represent renewable solutions that can give cost-efficient power supply with positive developmental, social, health, and environmental performance as compared to traditional centralized power supply.

Biomass is the main source of energy use in Mozambique (78\%). The second largest energy source consumed is hydropower (13\%) followed by oil products (7\%). The total electricity installed in the country in 2017 was about $2428 \mathrm{MW}$, the majority of this, 95\% stem from hydropower. As mentioned above, the main source of electricity is the HCB plant at Tete located in the Zambezi River Basin [10]. The access to electricity in Mozambique is $\sim 27 \%$ with $\sim 60 \%$ of the consumers living in cities and $40 \%$ in rural areas [12]. 
The urbanization process in Mozambique is strong and further strengthened by the fact that rural economic development lags behind urban development. Hydropower energy has been identified as having a strong potential for catalyzing social change and supporting development, providing opportunities for a broad range of activities that can improve the economy and the quality of life for the rural population in particular.

The nexus approach for water-energy-food has been promoted as a tool for sustainable development $[13,14]$. The framework for a nexus approach is integrated solutions to reduce future risk to resource scarcity. The approach is reasonable since increasing interconnectedness over sectors can increase overall resource use efficiency, and as well, contribute to the SDGs. The nexus approach has been developed and tested for several regional areas [15-17]. Studies on this approach for Mozambique, however, are almost completely lacking. A few studies provide results on larger scales such basin or general policy level $[18,19]$. Thus, we suggest a bottom-up approach to capture local opportunities for sustainable development [20]. In view of this, the present paper investigates the potential energy demand of a typical remotely located rural area in Mozambique and how it can be supplied by off-grid small hydropower energy in order to be sustainable in a nexus approach. We are especially interested in developing a mini-grid hydropower system that is economically viable and affordable by the poor rural population and that can be combined with food production or processing. Such systems can be part of the solution to increase the access to electricity in rural areas in Mozambique and thereby combat poverty by supporting sustainable development. Thus, the objectives of the present study were to (1) to investigate how a bottom-up nexus approach can be applied to rural Mozambique, (2) explore possibilities for a diversion type mini-grid run-of-river hydropower plant in the nexus approach, and (3) examine economic drivers for an improved nexus approach.

\section{Characteristics of Hydropower in Mozambique}

Mozambique has considerable water resources and hydropower potential through thirteen major river basins. In the direction from south to north these are Maputo, Umbeluzi, Incomati, Limpopo, Save, Buzi, Pungwe, Zambezi, Licungo, Ligonha, Lúrio, Messalo, and Rovuma. Mozambique is a downstream country, sharing with other countries nine of the fifteen basins in the Southern African Development Community (SADC) region. Substantial river discharge with steep gradients provides a high potential for development of hydropower schemes of all types, from pico- and mini- to smalland large-scale hydropower plants.

The development of renewable energy in Mozambique dates back to the colonial period, when hydropower plants were developed to supply electricity to large urban cities such as Maputo, Beira, and Nampula and for selling energy to South Africa [21]. In 1950, the Mavuzi hydropower plant was established (456 GWh/year) and in 1960 the Chicamba hydropower plant was built (333 GWh/year) on the Revue River in Manica Province. These two hydropower plants are still generating electricity, mainly supplying Beira and Chimoio and industry in the central part of Mozambique. In 1975 the construction of the HCB was completed and in 1987 the Curumana hydropower plant on the Sabie River in Maputo started producing electricity with a capacity of 16 MW [22].

The potential for hydropower in Mozambique has been estimated to 12-18,000 MW [5,22-24]. More than $80 \%$ of this is located in the Zambezi River Basin. However, only 2200 MW have been developed in a manner providing access to the national grid (Figure 2). In Figure 2, all types of large power plants in Mozambique are presented, including thermal gas power (red), coal thermal power (black), and hydropower (blue). To meet the existing needs, the government of Mozambique has made rural electrification a major component of its development programs [25]. In addition, it has tried to liberalize the energy sector of the country to better accommodate the influx of direct foreign investments into hydroprojects.

The present grid system is in need of restoration [9,23-28]. The grid is constituted by three separate systems with no interconnection: a southern, a central, and a northern system [9] (Figure 2). The electricity supply is therefore often intermittent and large parts of the rural areas are not 
connected [29]. Approximately $25 \%$ vanish in general transmission losses. It is not likely that the national grid can be extended to cover most of the rural areas in a foreseeable future [30].

The Mozambique government has set a number of broad policy objectives relating to the development and governance of the energy sector with a total investment of about 1.2 million USD [31]. It has also tried to support rural electrification through creating an enabling environment for the stakeholders involved [7].

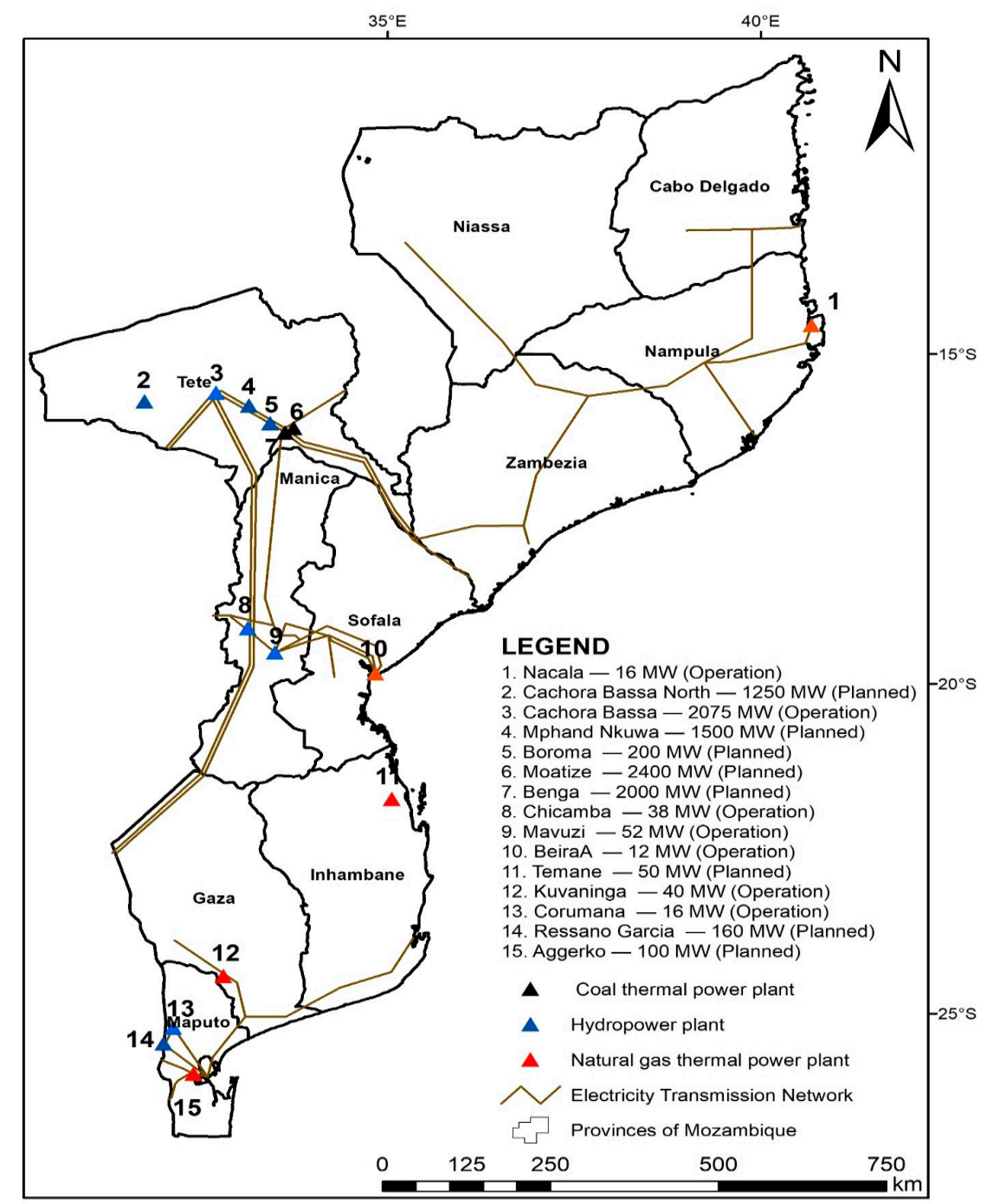

Figure 2. Outline of the three main grid systems in Mozambique with existing or planned large power plants. Source: own illustration with information from $[5,7,26]$.

Figure 3 shows the renewable energy and hydropower potential depending on province in Mozambique. Rainfall and topography offer the greatest hydropower potential in the Zambezi River Basin at sites such as HCB and Manica (Mavuzi and Chicamba with $80 \mathrm{MW}$ of power output) on the Revue River, as shown in Figure 3 [5]. 


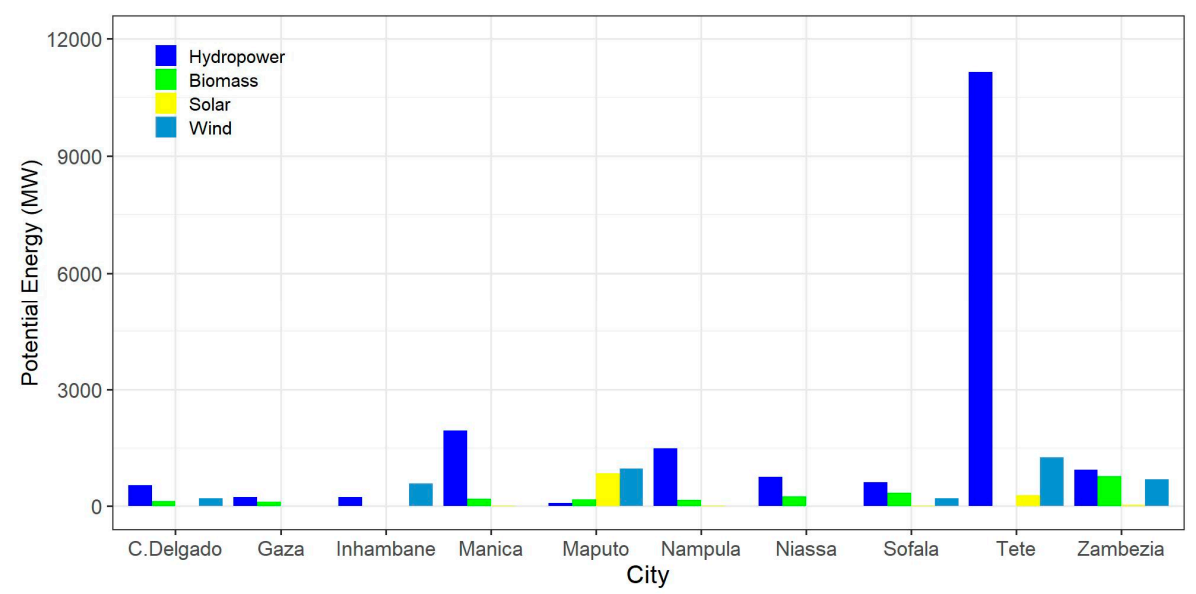

Figure 3. Hydropower potential and other forms of renewable energy in Mozambique. Source: own illustration with information from [7,32].

\section{Materials and Methods}

\subsection{Area Description}

The study area is located in the Chua Village along the Chua River, Mozambique. Chua is a small village with about 3000 inhabitants located in Maridza administrative post close to Manica City in the District and Province of Manica. Chua River Basin is located in the uppermost part of the Pungwe River Basin just at the border to Zimbabwe in the central western part of Mozambique (21 ${ }^{\circ} 34-16^{\circ} 24$ latitude $S$ and $34^{\circ} 01-32^{\circ} 42$ longitude W) [33,34] (Figure 4). The average annual rainfall is $\sim 1340 \mathrm{~mm}$ and runoff $\sim 477 \mathrm{~mm}$ [33]. An experimental catchment was chosen so as to represent a typical small hilly rural basin close to the Chua Village. The selected basin is a hilly branch of the Chua River covering about 9.6 $\mathrm{km}^{2}$. The surface use is mixed grazed areas with groves along the river. A few homesteads are included in the catchment area. Typically, families live at homesteads quite remote from each other. The main economic income is from agriculture, livestock, and artisanal gold mining. Chua area has previous experience of donor-assisted small-scale hydropower [35]. Deutsche Gesellschaft für Internationale Zusammenarbeit (GIZ) is active in the area for capacity building, technical, and economic assistance. Existing micro-hydropower plants are often privately owned while grid systems are usually owned by communities [35].

The area of Manica District is $\sim 4391 \mathrm{~km}^{2}$ and it has a population of $\sim 215,300$ inhabitants, with a density of 49 inhabitants $/ \mathrm{km}^{2}$. The Manica Province covers $61,661 \mathrm{~km}^{2}(7.7 \%$ of Mozambique) and borders the Tete Province to the north, by the Luenha and the Zambezi Rivers, the Provinces of Gaza and Inhambane to the south, by the Save River, Sofala to the east, and the Republic of Zimbabwe to the west. The climate is tropical and modified by altitude with a tendency of hot and humid weather. The rainy season is from September to March and the dry season from April to August. The average summer temperature is $\sim 20^{\circ} \mathrm{C}$, occurring most of the time in about half of the province. The warmest temperatures $\left(\sim 25^{\circ} \mathrm{C}\right)$ occur in the Save and the Zambezi Valleys. The coolest temperatures (15 to $20^{\circ} \mathrm{C}$ ) occur in the districts of Gondola, Manica, Mossurize, Báruè, and in the mountainous western parts. Average annual rainfall is about $1400 \mathrm{~mm}$. In drier regions, the annual rainfall is up to $700 \mathrm{~mm}$ and can reach $1800 \mathrm{~mm}$ in the interior highlands [34]. The mountains are located mainly in the far west, at an altitude of more than $1000 \mathrm{~m}$, near the border to Zimbabwe. This area has the highest altitudes up to $2436 \mathrm{~m}$ (Mount Binga).

The renewable energy potential in Manica Province has been estimated to $1941 \mathrm{MW}$ from hydropower, $25 \mathrm{MW}$ from solar, and $187 \mathrm{MW}$ from biomass [7]. The region is well-suited for small-scale hydropower. Main rivers run from west to east, following the topography. Manica Province includes the following watersheds and hydropower plants (Figures 4 and 5) $[25,26,32,36]$. 
- Zambezi River Basin, in the far north, with the rivers Luenha, Nhamakombe, and Pompue as main tributaries.

- Pungwe River Basin, in the central region, has Nhazonia and Vanduzi rivers as main tributaries.

- Búzi Basin that consists of Búzi, Revué, and Lucite Rivers.

- Save Basin in the extreme south, which has as main tributaries the Save, Vumaúzi, and Súrué Rivers.

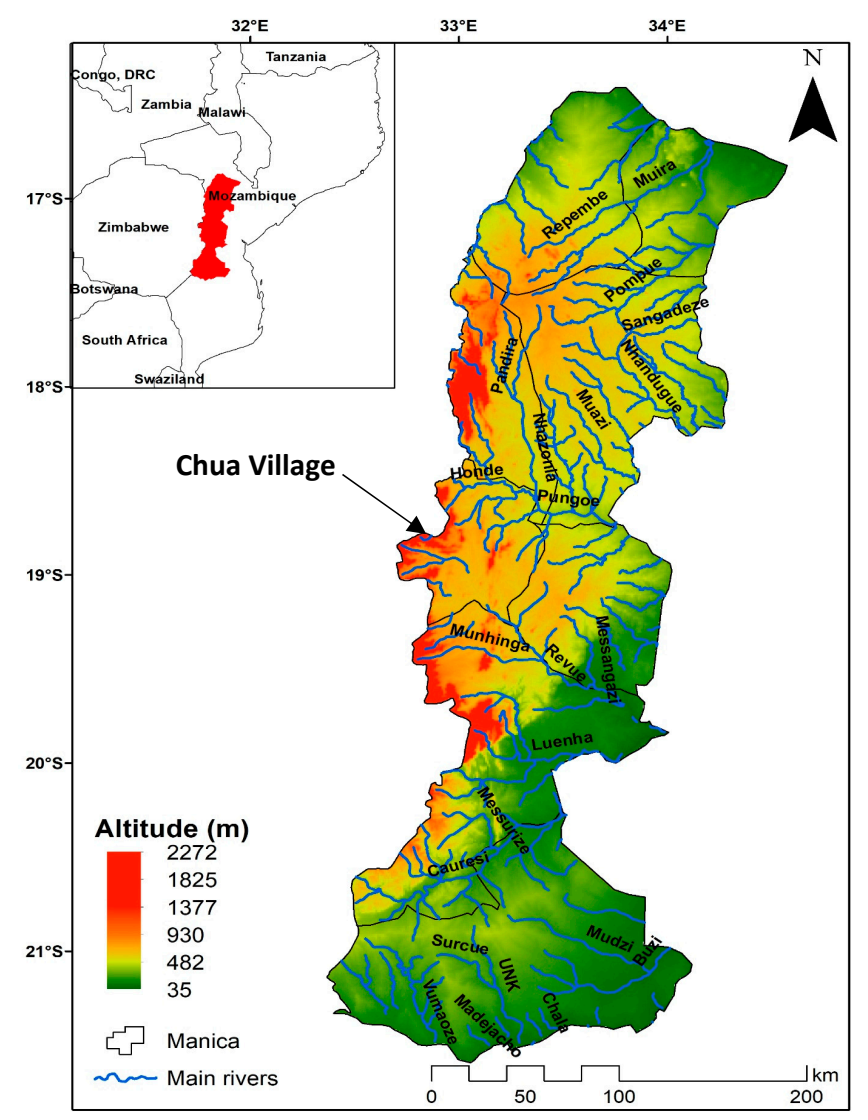

Figure 4. Major river basins, topography of Manica Province, and location of Chua Village. Source: own illustration.

Western Manica Province has many rivers and streams with perennial flow and suitable conditions for construction of micro-hydropower plants. Several locations for implementation of potential small hydropower projects have thus been identified such as Honde, Bárue District, Rotanda, and Sussundenga District [34]. The total power potential of these projects is $2000 \mathrm{~kW}$. One area with a high potential for hydropower production is the Chua region along the Chua River, which has been partly exploited already, through the construction of five small hydropower plants. These have a total power of $1200 \mathrm{~kW}$ and an annual electricity production of 10,500 MWh [37].

Due to the abundance of water resources, Manica Province has good agricultural potential. More than $90 \%$ of its $\sim 2.4$ million people are engaged in subsistence agriculture (2017) [4]. The area has a high poverty level, however, and the population suffers from recurrent high degrees of malnutrition. Staple food crops are rainfed maize, sorghum, pulses, and groundnuts. Access to electricity in agriculture is almost nonexistent. The province was severely affected by the 16 year civil war that ended in 1992. More or less all social and economic infrastructure was destroyed and this is still gradually being rebuilt [34]. Health and medical service is scarce and of poor quality. Access to education is unsatisfactory, especially for girls. The literacy level is $\sim 56 \%$. Approximately $77 \%$ of the area are covered by forest and forest resources plus charcoal constitute $80-90 \%$ of the energy consumed [4]. The electrification level is $\sim 8 \%$ in Manica [12]. 
Appoximately $51 \%$ of the Chua Village population are illiterate, men are often more illiterate due to that women are more involved in economic and social activities [38,39]. Chua Village covers two valleys and surrounding mountains. Households are generally located at far distance from each other. Average household size is 5.5 persons [39]. Approximately $74 \%$ had access to radio, $25 \%$ television set, and 30\% mobile phone in 2003 although without grid connection [38]. Electricity access is often done by solar panels, car batteries, or diesel generators. Approximately $25 \%$ suffer from malaria and $20 \%$ from respiratory diseases. On average $15 \%$ of the villagers use solar panels and car batteries as power for radios and some even for television. This is an indication of already existing demand for electricity. In a study from 2007 [40], most of the villagers (75\%) stated willingness to pay for the electricity. However, they were reluctant to express what amount of their disposable income that they could use for these additional expenses.

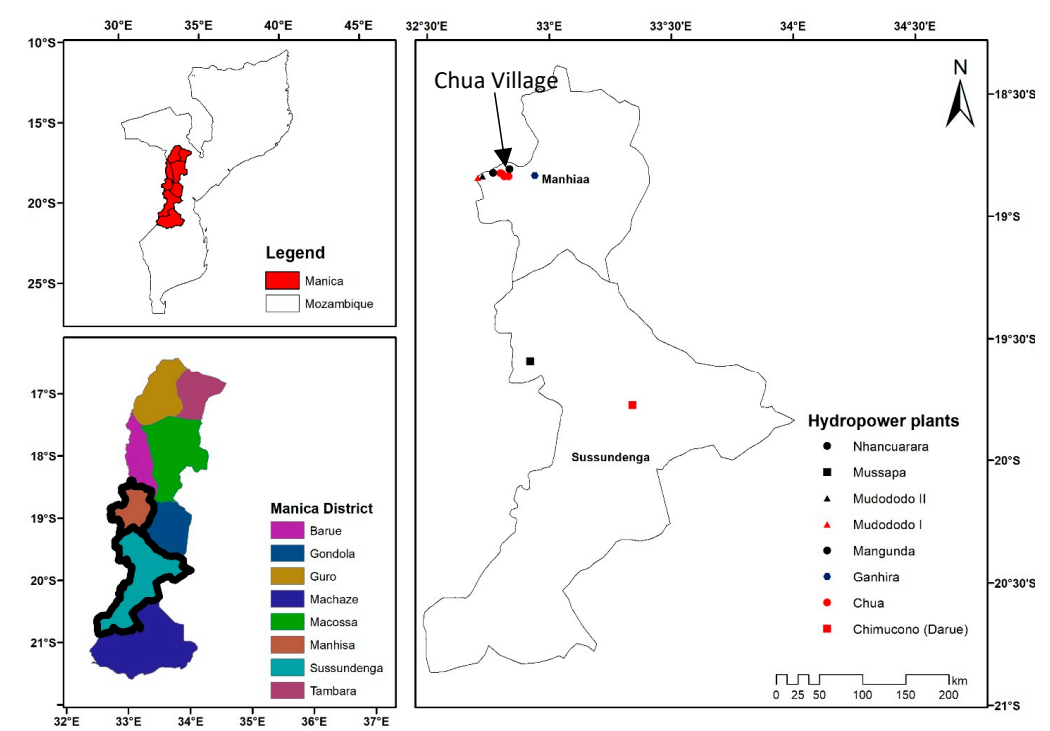

(a)

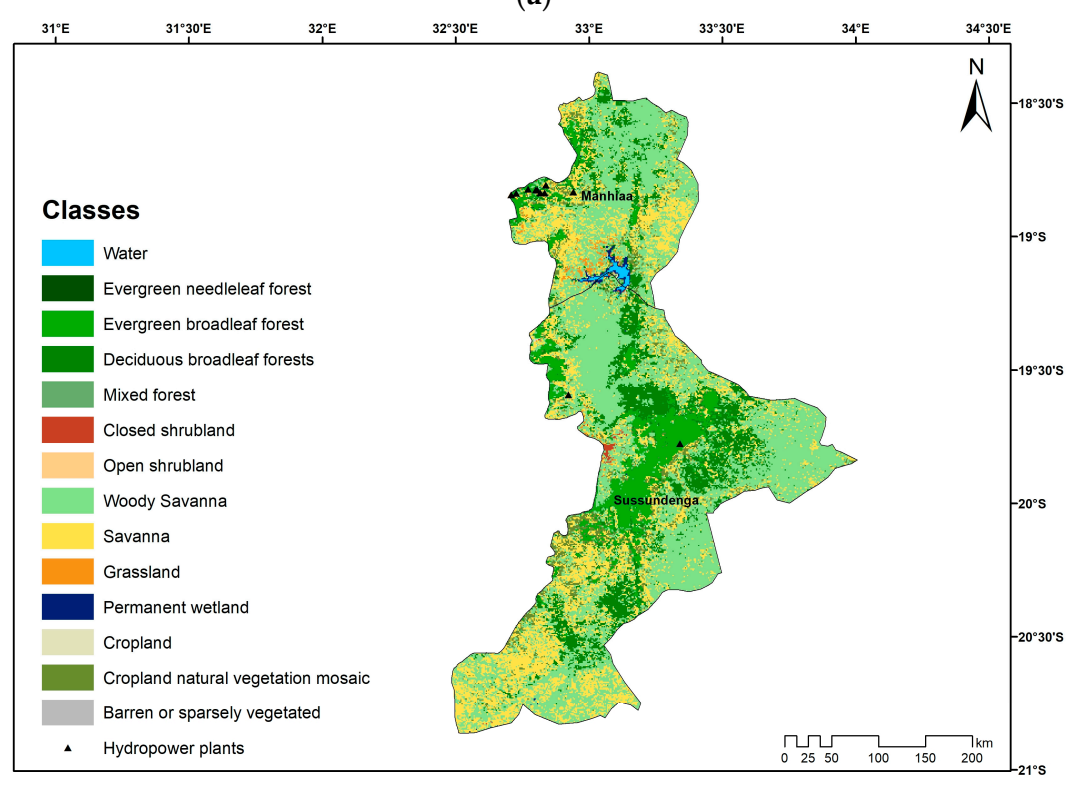

(b)

Figure 5. Chua Village location. (a) Manica Districts and location of major hydropower plants (b) Main surface use. Source: own illustration with information from $[25,26,32,36]$. 


\subsection{Methods}

Data and information collection were performed during study visits to Manica and Chua Village during July 2015 and June 2016. Data scarcity and lack of information are general problems in Mozambique. A law to provide free access to information was approved in 2014 (Law on freedom of information) [41]. Thus, to some extent, the data and information used in the present paper could be collected from official documents. Initial literature surveys and qualitative document analyses [42] were combined with semistructured interviews [43] in Chua Village during the study visits. Literature surveys and document analyses gave important insights on national electrification policies of Mozambique that could be compared to at-site conditions and interview results with local power plant managers and consumers in Chua Village and Manica District. Deeper literature surveys on sustainability gave input to the methodology that was used to understand relationships between electrification and sustainability goals [44-48].

Figure 6 shows the methodological framework for this study. Other studies have previously indicated that future hydropower development in Mozambique needs to be nexus-oriented [18]. However, to the best of our knowledge, this has previously not been shown for Mozambique using a bottom-up approach. We see the economic drivers for sustainable development of rural electrification as especially important. Since the rural population is very poor, the willingness to pay for energy services is low. Thus, also other incentives for financing small-scale hydropower have to be considered. At the same time, hydropower development and the use of water are intrinsically linked to water supply and food production.

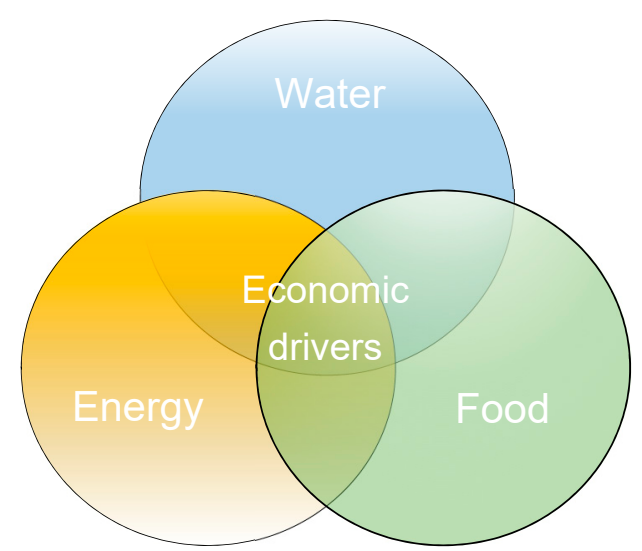

Figure 6. Methodological framework for rural electrification in Mozambique with a local nexus approach. Source: own illustration.

A key investigation objective was to analyze local needs of electricity to match possible supply. In general, the research focused on five key demand groups namely, households, small business, public infrastructure, small industries, and leisure time activities. For households, in total 50 face-to-face interviews with mixed electrified/nonelectrified household representatives were conducted in effort to understand how much hydropower is appropriate for the population in the investigated area. It was especially important to elucidate the major needs of electricity in the community. The village head was interviewed in order to get an overview of total needs of the village. Interview results were recorded using handwritten notes taken during the interviews and supplemented by additional notes just after the interview events. A checklist was used to find answers concerning household structure and basic needs of electricity such as how they light their houses, their health, water use, and washing, refrigerator, cooking requirements, leisure activities, and appliances uses. Questions were also asked regarding views on public lighting, local hospital use, as well as village administration, primary school conditions, and ideas on business opportunities.

Five hydropower operators in Manica District were interviewed during the study visits. During each interview, questions were asked to elucidate institutional and organizational conditions, 
economic aspects, environmental conditions, and sociocultural features. Study visits and interviews were also made with key professionals such as the GIZ offices in Chimoio, the capital of Manica. GIZ finances projects concerning renewable hydropower energy produced in this region of Mozambique. Special interviews were made with the plant manager at the Chua Power Plant regarding the use of hydropower for milling purposes. Other institutions that provided us with information were EDM (Electricidade de Moçambique), UNIDO (United Nations Industrial Development Organization), Ministry of Energy of Mozambique, and FUNAE (Fundo de Energia).

The objective of the fieldwork was also to visit possible locations for a diversion type mini-grid run-of-river hydropower plant, collect data on topography and discharge, and analyze connection possibilities to the Chua Village. The general layout of a run-of-river hydropower plant system is shown in Figure 7. The layout consists of a dam, a penstock, a powerhouse, an electric power station, and a distribution line connecting to the users. In general, the detailed layout needs to be adapted to each specific case. However, a run-of-the-river layout is generally applicable to mini- and micro-hydropower plants. Storage reservoirs are not commonly used in connection to these. However, it is important that small hydropower systems can supply several houses with electricity and possibly also can contribute to balance larger grids.

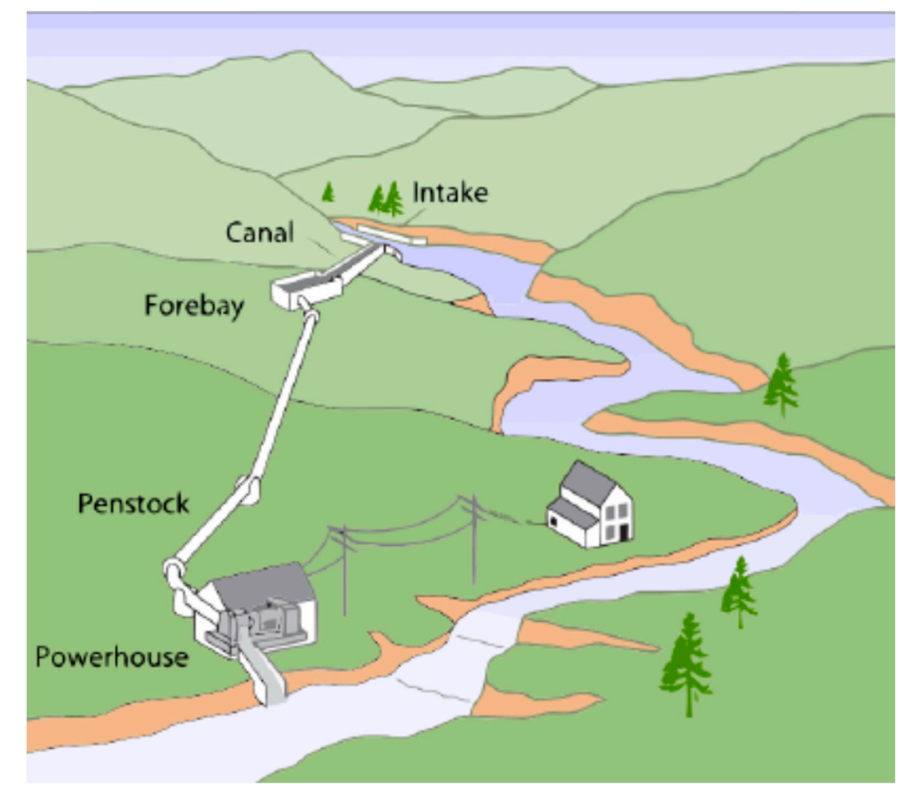

Figure 7. Schematic outline of a typical diversion type run-of-river small hydropower plant that can be connected to a mini-grid system. Source: $[49,50]$.

\section{Results and Discussion}

In the late 1990s, when peace came to Mozambique, a decade of marked development in the Chua area began. The German organization GIZ modernized parts of a system employed for milling corn. A hybrid system was developed for producing electricity to approximately 50 families, and a school and a hospital were built. Today, the area has five small hydropower plants, including the Tomás Wiston Ngurai plant that supplies 36 houses; the Gimy Pondo plant supplying 30 houses, as well as a hospital, twenty small shops, and four public lighting posts; and the Stephen Benjamim Mucheca plant supplying 30 houses, a school, a hospital, fifteen small shops, and four streetlights. Nevertheless, only a small portion of the Chua Village population is yet supplied by electricity. To motivate the societal buy-in to reach the SGD goal of $100 \%$ electrification by 2030, the demand for and use of electricity must be increased. At present, there is a marked difference between the production and the consumption of electricity. Mozambique produces large amounts of hydropower and has several hydropower projects underway besides the Mphanda Nkuwa such as the North Bank project (1245 MW), the Lupata project 
(600 MW), the Boroma project with a capacity of $200 \mathrm{MW}$, and the Lurio project (120 MW) [24]. A major part of this is, however, destined for export.

To contribute meaningfully to the electrification ambitions of 2030, two important prerequisites need to be fulfilled. The first is to work with the local population so as to engage these in the ambitions. Careful mapping of the local needs is very important. The second concerns the cost and ability of the locals to pay connection and operation fees. Figure 8 shows a comparison between the capacity of existing major hydropower plants in Mozambique and the cost per MW $[7,26]$. The largest plant is obviously constituted by the HCB. Even though there is no simple relationship between size and cost, several of the smaller hydropower plants have similar low cost as the large HCB plant. It is thus reasonable to expect that larger hydropower plants would be more economical due to higher efficiency at large-scale vs. small-scale [51]. A further advantage of large-scale vs. small-scale hydropower systems is that large-scale systems can efficiently store energy and thus, they are more resilient against both climate variation and climate change.

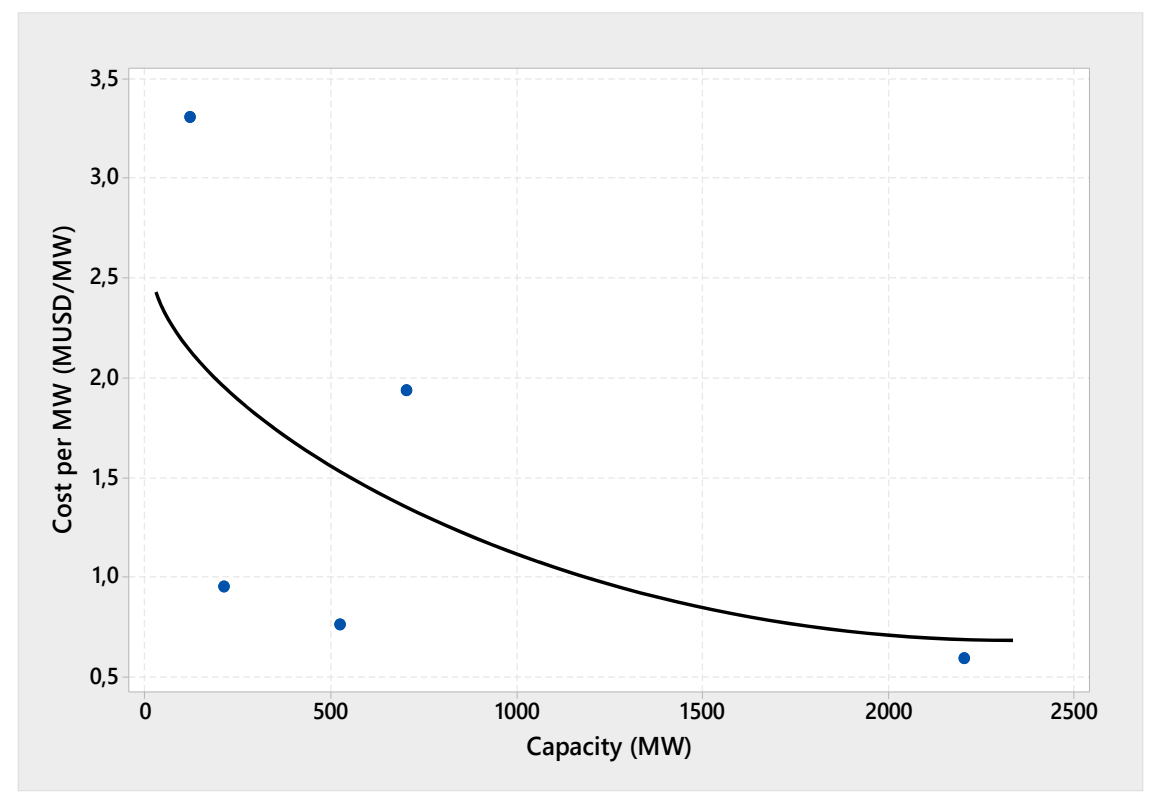

Figure 8. Relation between capacity of existing hydropower plants in Mozambique and their investment cost per MW. Source: own illustration with data from $[7,26]$.

In general, the investment cost for small-scale hydropower in Mozambique has been estimated to $\sim 570$ USD/MWh while for large hydropower plants 230 USD/MWh [7]. Regarding the possibility of investing in wind energy, most of the projects of this kind identified by FUNAE have an investment cost of between 50 and $100 \mathrm{USD} / \mathrm{MWh}$, whereas the solar energy facilities have an investment cost of $\sim 100$ to 150 USD/MWh [7,32]. The investment cost of biomass-fueled plants in Mozambique is $\sim 100$ USD/MWh [7]. The production cost of electricity in a hydropower plant can be rather low as compared to other forms of renewable energy, partly due to that the fuel involved is freely available water supplied by sun energy. The cost of electricity that is generated by large-scale hydropower ranges from 20 to $190 \mathrm{USD} / \mathrm{MWh}$ [52].

Table 1 presents potential small hydropower plants that have been identified in Manica Province [4] in collaboration with GIZ. With the objective of promoting rural electrification through providing renewable energy to reduce dependence upon fossil fuel consumption and of reduce poverty, GIZ has developed a program for financing small hydropower plants in Manica. Thus, GIZ helps the government of Mozambique to carry out the rural electrification program. Without this program, Manica would experience many difficulties in electrification since people are living scattered throughout the rural area under low income conditions. Most of the identified locations for small 
hydropower plants represent power supply of 8 to $60 \mathrm{~kW}$. Most of these are probably well-suited for diversion type run-of-river small hydropower plants. However, many of them are expected to be even simpler type of generators that the villagers are assumed to partly build and maintain themselves with a small monetary compensation and technical help from GIZ.

The interviews in Chua Village identified potential consumers of electricity according to Table 2. In general, interviewed people with access to electricity were quite unanimous in their belief that electricity had done much to change their lives for the better. Examples were given such as the creation of many small businesses and possibilities to communicate with distant family members. The rural household representatives were happy to have electricity for lighting their homes, watching television, listening to radio, and for different leisure activities, as well as for cooking and making life in general easier. According to the village head, $~ 520$ households are in need of electricity. Other important public infrastructure is a hospital, a primary school, and a church. Besides these, there are four small shops, one administrative office, two grain mills, and two bars. According to the village head, besides households, prioritizing the hospital, primary school, and church is important. The shops, administrative office, grain mills, and bars have electricity access through sun panels and batteries or diesel generators. One of the grain mills is an old hybrid type used for both electricity generation and grain milling.

Table 1. Potential small hydropower plants in Manica Province [4].

\begin{tabular}{cccc}
\hline Watershed & Zone & District & Capacity (kW) \\
\hline Mussambizi & Honde & Barue & 70 \\
Mussambizi & Panze & Barue & 60 \\
Rotanda & Rotanda & Sussundenga & 30 \\
Bonde & Sembezeia & Sussundenga & 60 \\
Nhamangwena & Sembezeia & Sussundenga & 30 \\
Nhamutsawa & Chôa & Barue & 200 \\
Nhazónia & Nhamussarara & Barue & 15 \\
Revúe & Mucudo & Manica & 8 \\
Dawawa & Mavonde & Manica & 17 \\
Chua Lino & Chua & Manica & 22 \\
Chua Mucheca & Chua & Manica & 18 \\
Chua-Nguarani & Chua & Manica & 22 \\
Chimucono & Chua & Manica & 26 \\
Mangunda & Chua & Manica & 26 \\
Mudododo & Chua & Manica & 32 \\
Mussapa & Chua & Manica & 20 \\
Nhancurara & Chua & Manica & 26 \\
Ganhira & Chua & Manica & 16 \\
Chua-Gim & Chua & Manica & 18 \\
\hline
\end{tabular}

The electricity use that the households most often stated was lighting, ironing, television/radio, and mobile phones. Occasionally refrigeration was mentioned. For most villagers, however, a refrigerator implies a too high investment and energy consumption. For the hospital, primary school, and church, lighting was the first choice. Hospital representatives mentioned sterilization as an important use of electricity. Identified needs for each person in Chua Village households would approximately correspond to $3.0 \mathrm{kWh} /$ day or $1100 \mathrm{kWh}$ per capita and year. Assuming that each household consists of 5.5 persons, Chua Village total needs would correspond to $3100 \mathrm{MWh}$ (Table 3). The communal needs for the hospital, primary school, and church, would be added to this figure (75 MWh/year). Thus, total needs would correspond to $3175 \mathrm{MWh} /$ year (Table 3).

In general, the stated needs for electricity are more than twice the average consumption of electricity in Manica Province (1100 as compared to $453 \mathrm{kWh}$ per capita and year) [53]. Using the lower figure for the total needs corresponds to $\sim 1300$ MWh per year for the Chua Village (Table 3). Thus, stated needs appear to be much larger than existing average use. This would also mean that 
needs are real and exceeding supply. After adding communal needs, the total would add up to about $1375 \mathrm{MWh}$ /year (Table 3).

Table 2. Potential consumers of electricity in Chua Village.

\begin{tabular}{ccc}
\hline Type & Consumer & Total \\
\hline Private home & Households & 520 \\
Small business & Shops & 4 \\
& Hospital & 1 \\
Public infrastructure & Primary school & 1 \\
& Church & 1 \\
Small industry & Administrative office & 1 \\
Leisure & Grain mills & 2 \\
\hline
\end{tabular}

In total, about one year of discharge records exist for the Chua River close to the village. The average discharge during the one-year observation period was $\sim 0.15 \mathrm{~m}^{3} / \mathrm{s}$. The head for the potential diversion type run-of-river small hydropower plant was identified as $\sim 50 \mathrm{~m}$. This would yield an output power of $\sim 60 \mathrm{~kW}$ ( $\sim 80 \%$ efficiency) [49,50,52]. Consequently, a turbine would give a possible energy of $\sim 500 \mathrm{MWh}$ per year. In turn, this would imply that $\sim 80$ households could be supplied by energy for the documented need of 3100 MWh per year. On the other hand, if the lower rate of needs (average for Manica Province as a whole) equal to 1300 MWh per year is accepted, this would mean that about 200 households could be supplied by electricity.

Table 3. Total energy needs and payment capacity of Chua Village assuming (a) 1100 (results from interviews) and (b) 453 (average for Manica Province) kWh per capita and year, respectively.

\begin{tabular}{ccccc}
\hline $\begin{array}{c}\text { Number } \\
\text { of Households }\end{array}$ & $\begin{array}{c}\text { Household } \\
\text { Needs } \\
\text { (MWh/year) }\end{array}$ & $\begin{array}{c}\text { Communal } \\
\text { Needs } \\
\text { (MWh/year) }\end{array}$ & $\begin{array}{c}\text { Total } \\
\text { Needs } \\
\text { (MWh/year) }\end{array}$ & $\begin{array}{c}\text { Payment } \\
\text { Capacity } \\
\text { (USD/MWh) }\end{array}$ \\
\hline (a) 520 & 3100 & 75 & 3175 & 8 \\
(b) 520 & 1300 & 75 & 1375 & 19 \\
\hline
\end{tabular}

The payment capacity of poor rural villagers in Mozambique has been estimated in several studies. Rural households without access to electricity have been estimated to potentially be willing to spend about 50 USD annually (out of 300 USD annual income) on substitute products like kerosene and batteries [18,54]. Another study estimated the willingness of $93 \%$ of rural households to spend $\sim 48$ USD per year on electricity [40]. Since both results are fairly close, $~ 50$ USD per household and year appear to be realistic. Thus, the payment capacity for households would correspond to 8 and 19 USD/MWh for the two cases in Table 3. It is interesting to note that the payment capacity in Table 3 (assumed average of $453 \mathrm{kWh}$ per capita and year) is close to the lower limit of cost for generated large-scale hydropower as discussed above (20 USD/MWh). Thus, it appears that there are real economic incentives to supply rural Manica with hydropower. To further improve economy, small-scale hydropower schemes can be planned to be connected to small-scale business initiatives to further promote profitability. An example of this is shown below.

The above case study example shows that the investigated diversion type run-of-river small hydropower plant (500 MWh per year) is not enough for the total needs of Chua Village. The supply from the plant would give energy for 80-200 of totally 520 existing households. Including all electricity needs according to Table 3, the village would need 2 to 5 more similar-sized plants to fulfill all energy needs. The example shows the inherent difficulties involved in supplying remote rural areas in Mozambique with electricity. However, the example also indicates that the villagers have a real payment capacity of between 8 and 19 USD per MWh and year. Adding capacity for pumping surface or groundwater for domestic use or irrigated agriculture would further add to the above electricity 
needs. Thus, it is important that each small-scale hydropower project identifies local needs and economic drivers such as payment capacity and possibilities for connecting local small-scale business.

Figure 9a shows the return flow to the river from the powerhouse for one of the existing electricity generators in the area. The generator is a diversion type run-of-river small hydropower plant that gives $\sim 12 \mathrm{~kW}$ for an average flow of $\sim 0.08 \mathrm{~m}^{3} / \mathrm{s}$. The powerhouse contains a Pelton turbine, transformer, generator, and milling equipment. This is a typical hybrid system used for grinding grain. The turbine receives water from a small reservoir through a penstock and then leaves the powerhouse through a draft tube back to the river. The head is $\sim 75 \mathrm{~m}$ and the turbine gives electricity to 130 households. The mill and turbine are part of a small-scale business that generates return to private investors. In a similar manner, to increase the economic profitability of the above suggested mini-grid hydropower system small-scale industry would need to be included. For the studied Chua Village, this would preferable be constituted by a small-scale factory for milling of corn and other cereals. Rural electrification in Mozambique would therefore also be part of the important water-food-energy nexus. This means that rural water management in a sustainable manner would contribute to energy, food production, and processing.

Mozambique's electrification challenges are common to many sub-Saharan countries [18]. The situation for Mozambique, however, is unique in that it has huge hydropower resources that can be commonly developed between many sub-Saharan countries. The challenges include developing new infrastructure, develop institutional framework, and increase ability to pay for energy. The solution is complex and scale-dependent. At the largest scale, national grids need to connect regions across country borders to support large-scale economic development [18]. This is likely only realizable in the longer time scale. Developing an institutional framework for small-scale power allowing for increasing willingness pay for energy services is a goal that probably can be reached in the short-term. A nexus approach founded at the local scale also involves economic drivers and security by connecting small-scale hydropower to local industrial enterprises. Access to electricity will spur improved water supply that can improve health and food production. There are, however, also environmental challenges. Figure $9 \mathrm{~b}$ shows an example of sediment transport in a nearby small river as a result of upstream deforestation and artisanal gold mining. Small-scale gold mining gives households an important extra income to the subsistence agriculture. However, this also leads to destroying the natural forest, serious erosion problems, and siltation in downstream reservoirs. Due to inappropriate use of mercury in the gold amalgamation process, serious pollution problems occur both in soil and downstream water [55]. It is thus important that authorities and environmental organizations set up a framework for small-scale gold mining.

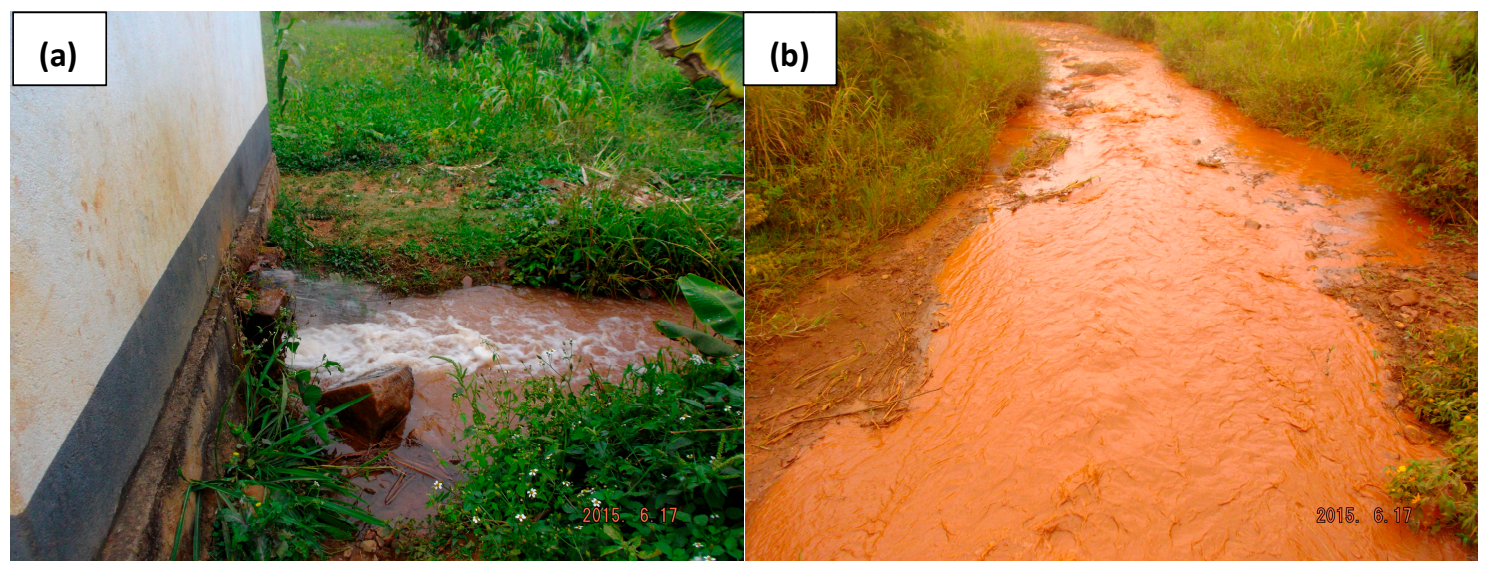

Figure 9. (a) Outside of the powerhouse for one of the area's hybrid generator for electricity and grain milling with return flow to the river. (b) Example of sediment transported by the river water as a result of upstream deforestation and artisanal gold mining (photo by Miguel M. Uamusse). 
Small-scale hydropower presents some general advantages over other renewables such as solar power for rural Mozambique at locations like Chua Village. Total solar power use is at present very small but growing steadily in rural areas due to general affordability, ease of use, and simple installment [56]. Solar power systems, however, contain hazardous constituents and batteries such as, e.g., heavy metals [57]. There is no system or infrastructure for reuse or collection of old batteries and other parts of used solar panels in rural areas of Mozambique. Consequently, especially regarding the rather short lifespan of solar panel systems, used parts and old batteries are likely to end up in the general waste deposits of the rural villages. Solar panels are as well accessible for theft. Small-scale hydropower is a simple and well-proven technique with simple parts. Faulty or worn parts can often be manufactured or repaired by the village smith or other handy villagers. Since there is a long tradition to use small-scale hydropower in many rural areas in Mozambique, rural villagers often have a good understanding of how to plan, build, and maintain small hydropower plants. Small-scale hydropower, as it is used in hilly areas of rural Mozambique, has a greater net capacity (ratio of actual electrical energy output to maximum possible electrical energy output over time) than, e.g., solar power. In general, hydropower also represents greater efficiency as compared to solar power. Due to that small streams in rural Manica hilly areas often drain groundwater (or springs); the seasonal variation in flow may be rather small due to that a large part of the discharge is base flow that gives a rather stable mean discharge rate.

On the one hand, small-scale hydropower requires a larger investment cost and available capital compared to family-based solar panel systems. On the other hand, small-scale private businesses may be benefit from investing in hydropower and enjoy a stable economic return. Additionally, small-scale hydropower, linking a group of households together in a mini-grid system, may improve the socioeconomic cohesion of the scattered rural homesteads. Climate change is likely to affect the future river flow by less annual rainfall, increasing interannual variability, and smaller dry season river flow [58]. In this context, small-scale hydropower is more vulnerable and less resilient as compared to large-scale hydropower and other renewables. In view of this, it would be better to have a national mix of renewable energy sources for a greater resilience against climate variation and climate change.

Achieving sustainable development of rural areas in Mozambique requires electrification. Access to clean and affordable electricity is crucial to improve standard of living in Manica as well as the country as a whole. However, many studies have pointed out, there are no obvious links between rural electrification and sustainable development [56]. An evident requirement for a successful implementation must always be strong individual, community participation, and engagement. The partial electrification of Manica has clearly improved living conditions, resulting in 300 electrified schools and hospitals. Access to electricity has improved educational facilities and made teaching and studying possible during dark hours. In Manica, the National Energy Fund (FUNAE) has concentrated on photovoltaic (PV) systems in schools, teachers' homes, hospitals and hospital workers' homes, and public sector services as well as providing pumps for drinking water. Rural electrification also generates improved environment, health, and safety conditions that will particularly benefit women and children [5].

The electrification of rural Mozambique is a scale and institutional problem. At a larger national scale, the Electricidade de Mocambique (EDM) works to extend the on-grid systems mainly for urban areas. Mini-grid systems located in rural areas are planned and supplied by FUNAE. Thus, the FUNAE supplements EDM by endorsing rural electrification where EDM does not provide service by the national grid due to too high costs. Additionally, off-grid systems using PV solar home systems are supplied by FUNAE [56]. At the smallest scale, GIZ and other donors efficiently support micro-grids and individual initiatives [35]. FUNAE uses a centralized approach emphasizing rural institutions rather than rural dwellers. Thus, there is a gap between the national SDGs and the needs of poor rural individuals. Fostering local ownership, capacity building, and stakeholder empowerment need further improvement [35]. Thus, barriers to small-scale hydropower development are lacking a framework to support small and independent power producers. Further, both public and private funding to promote 
lending to small-scale hydroprojects would be needed. Finally, a simpler approach for environmental impact assessment for small run-of-river hydro plants is warranted [35,59].

\section{Conclusions}

UN SDG 7 implies that all citizens should have access to affordable, reliable, sustainable, and modern energy by 2030. It is not likely, however, that Mozambique will reach this goal. Mozambique is a very poor country that has abundant energy supply and even if rural electrification is on its way, the progress has been somewhat sluggish. Even so, for areas that have been electrified, the effects on socioeconomic development stand out, such as educational benefits, income improvement, and health progress [56].

We investigated local needs of electricity in Chua Village in rural Mozambique. We found that part of these needs can be supplied by a new diversion type run-of-river small hydropower plant that can be connected to a mini-grid system. Up to $\sim 200$ of the 520 village households can benefit by electricity from this system. By combining the generator with a milling system for grains or other small-scale enterprise, the produced energy can generate a further small income for the owner such as individuals or community. A simple medium to high head (10-50 m) microturbine type (e.g., Pelton or Turgo) [50] can often be maintained and repaired by handy villagers or the village smith. This setup would be a contribution to the sustainable water management as well as an important part of a sustainable and resilient water-food-energy nexus.

For this reason, we suggest a bottom-up nexus approach to improve water, energy, and food security initiated at a local level. Households in the investigated case study area can be connected to a mini-grid hydropower system that can allow for energy production to 80-200 households. To increase the economic profitability of the mini-grid hydropower system we suggest including small-scale industry. For the studied rural village, this would be constituted by a small-scale factory for milling of corn and other cereals. Electricity produced can thus be used for food processing but also for pumping water supply to households for domestic use and small-scale irrigated farming lots. The results indicate that the villagers have a real payment capacity of between 8 and 19 USD per household and MWh. The payment capacity of villagers together with small-scale business initiatives presents an important economic local driver and business model for new small-scale hydropower plants.

We believe that the presented bottom-up nexus approach to improve water, energy, and food security initiated at a local level can be scaled up to other areas in Manica according to Table 1 and other provinces with similar characteristics regarding hydrology and topography. Manica Province is unique in the sense that it contains large hydropower resources. However, small-scale hydropower does not need large river flow as exemplified in this paper. Small rivers with suitable topography can be used to develop rural electrification, preferably in a bottom-up nexus approach with relevant economic drivers. In a longer term, rural development in a nexus approach may improve the economic conditions and as well improve environment by less needs for artisanal gold mining.

We argue that small-scale hydropower has advantages as compared to other renewables such as solar power systems. Small-scale hydropower is clean and renewable energy. The Chua villagers have previous experience in developing and maintaining small-scale hydropower. Authorities and donors can supply capacity building regarding efficiency and technical improvements along with small-scale economic incentives. It is important to build on local stakeholders' needs and individual motivations. Small-scale hydropower, however, is probably more sensitive to climate change. Thus, it is important to build the country's total energy production with a variety of resilient renewables, large-scale as well as small-scale.

We identified a number of ways to speed up the rural electrification in Mozambique. We believe that efficient rural electrification has to consider scale and institutional strengthening. The German organization GIZ has long experience of working at the local scale with rural poor, to efficiently support micro-grids and individual initiatives. There appears to be a lacking national framework, however, to support small and independent power producers. Strengthening this framework by loan 
possibilities, technical support, and a simpler approach to obtain consent from authorities would be needed.

Author Contributions: Conceptualization, M.M.U., K.T. and K.M.P.; methodology, M.M.U.; software, M.M.U.; validation, M.M.U., K.T. and K.M.P.; formal analysis, K.T.; investigation, M.M.U.; resources, K.M.P.; data curation, M.M.U.; writing—original draft preparation, M.M.U.; writing-review and editing, R.B.; visualization, R.B.; supervision, K.T.; project administration, K.M.P.; funding acquisition, K.M.P.

Funding: This research was funded by the Swedish International Development Cooperation Agency (SIDA), Eduardo Mondlane University, and Lund University.

Conflicts of Interest: The authors declare no conflict of interest.

\section{References}

1. UN. Goal 7: Ensure Access to Affordable, Reliable, Sustainable and Modern Energy for All. 2018. Available online: https:/ / unstats.un.org/sdgs/report/2017/goal-07/ (accessed on 4 September 2018).

2. UN. The Sustainable Development Goals Report 2016; United Nations: New York, NY, USA, 2016.

3. Bhattacharyya, S.; Palit, D. Mini grid based off-grid electrifications to enhance electricity access in developing countries: What policies may be required? Energy Policy 2016, 94, 166-178. [CrossRef]

4. INE. Instituto Nacional de Estatistica. Statistical Yearbook 2017-Mozambique. Maputo. Available online: http:/ / www.ine.gov.mz/ (accessed on 28 September 2018).

5. Mulder, P.; Tembe, J. Rural electrifications in an imperfect world: A case study from Mozambique. Energy Policy 2008, 36, 2785-2794. [CrossRef]

6. The World Bank. 2018. Available online: https://data.worldbank.org/indicator/EG.USE.ELEC.KH.PC (accessed on 28 November 2018).

7. FUNAE. Atlas das Energias Renováveis de Moçambique. Recursos e Projectos para Produção de Electricidade Maputo: FUNAE. 2013. Available online: http:/ /gestoenergy.com/wp-content/uploads / 2018/04/MOZAMBIQUE-RENEWABLE-ENERGY-ATLAS.pdf (accessed on 28 September 2018).

8. Electricidade de Moçambique (EDM). Available online: https://portal.edm.co.mz/en (accessed on 10 September 2018).

9. Cipriano, A.; Waugh, C.; Matos, M. The Electricity Sector in Mozambique, an Analysis of the Power Crisis and Its Impact on the Business Environment. USAID, Maputo. 2015. Available online: https://www. powerutilityleadership.com/wp-content/uploads/2018/02/Mozambique_Power_Crisis.pdf (accessed on 12 September 2018).

10. Hankins, M.A. Renewable Energy Plan for Mozambique. Justiça Ambiental (JÁ), Maputo, Moçambique, 2009. Available online: https:/ / www.internationalrivers.org/sites/default/files/attached-files/clean_energy_ for_mz_30_9_09.pdf (accessed on 20 September 2018).

11. Wolfgang Mostert Associates. Energy Sector Support Programme; Technical Review; DANIDA: Copenhagen, Denmark, 2006.

12. World Economic Forum (WEF). Water Security: The Water-Food-Energy-Climate Nexus; World Economic Forum: Washington, DC, USA, 2011.

13. Hoff, H. Understanding the Nexus: Background Paper for the Bonn 2011 Conference: The Water, Energy and Food Security Nexus; Stockholm Environment Institute: Stockholm, Sweden, 2011.

14. United Nations Economic and Social Commission for Western Asia (UN-ESCWA). Developing the Capacity of ESCWA Member Countries to Address the Water and Energy Nexus for Achieving Sustainable Development Goals; Regional Policy Toolkit; United Nations: Beirut, Lebanon, 2016; 219p.

15. Kulat, M.I.; Mohtar, R.H.; Olivera, F. Holistic water-energy-food nexus for guiding water resources planning: Matagorda County, Texas case. Front. Environ. Sci. 2019, 7, 3. [CrossRef]

16. Daher, B.T.; Mohtar, R.H. Water-energy-food (WEF) Nexus Tool 2.0: Guiding integrative resource planning and decision-making. Water Int. 2015, 40, 748-771. [CrossRef]

17. Bullock, A.; Hülsmann, S. Strategic Opportunities for Hydropower within the Water-Energy-Food Nexus in Mozambique; Working Paper-No. 4; United Nations University, Institute for Integrated Management of Material Fluxes and of Resources (UNU-FLORES): Dresden, Germany, 2015. 
18. Nielsen, T.; Schuenemann, F.; McNulty, E.; Zeller, M.; Nkonya, E.; Kato, E.; Meyer, S.; Anderson, W.; Zhu, T.; Queface, A.; et al. The Food-Energy-Water Security Nexus Definitions, Policies, and Methods in an Application to Malawi and Mozambique; IFPRI Discussion Paper 01480; Environment and Production Technology Division: Washington, DC, USA, 2015.

19. Biggs, E.M.; Bruce, E.; Boruff, B.; Duncan, J.M.A.; Horsley, J.; Pauli, N.; McNeill, K.; Neef, A.; Van Ogtrop, F.; Curnow, J.; et al. Sustainable development and the water-energy-food nexus: A perspective on livelihoods. Environ. Sci. Policy 2015, 54, 389-397. [CrossRef]

20. International Energy Agency (IEA). World Energy Outlook. Electricity Access Database. 2017. Available online: http://www.worldenergyoutlook.org/resources/energydevelopment/energyaccessdatabase/ (accessed on 3 September 2018).

21. Macaringue, D. The Potential for Micro-Hydro Power Plants in Mozambique. Literature Review and Project Proposal. University of KwaZulu-Natal. Pietermaritzburg. 2009. Available online: http:/ / efwe.ukzn.ac.za/ Libraries/ResearchSeminars/Macaringue_D.sflb.ashx (accessed on 20 November 2018).

22. Siebel, R.; Rafael, A.; Gulab, N. The Tsate HPP—Starting Signal to Overcome the Energy Scarcity in Central Mozambique. Lahmeyer International, Bad Vilbel, Germany. Available online: https://www. lahmeyer.de/fileadmin/alle/publikationen/Lahmeyer_Publication_03_2017_Starting-Signal.pdf (accessed on 22 November 2018).

23. AllAfrica. Interview with Mozambique Energy Minister Salvador Namburete. Available online: https: / / allafrica.com/stories/201405090422.html (accessed on 7 December 2018).

24. Hussain, M.Z. Mozambique-Energy Sector Policy Note (English); World Bank Group: Washington, DC, USA, 2015; Available online: http:/ / documents.worldbank.org/curated/en/135711468180536987/pdf/ ACS17091-REVISED-PUBLIC-Mozambique-Energy-Sector-Policy-Note.pdf (accessed on 12 September 2018).

25. Chambal, H. Energy Security in Mozambique. International Institute for Sustainable Development, Series on Trade and Energy Security Policy Report, Winnipeg, Canada, 2010. Available online: https:/ / energypedia. info/images/ff/f2/EN-Energy_security_in_Mozambique-Helder_Chambal.pdf (accessed on 5 September 2018).

26. EDM. EDM Strategy 2018-2028; Electricidade de Moçambique (EDM): Maputo, Mozambique, 2018; Available online: https:/ / www.edm.co.mz/en/document/reports/edm-strategy-2018-2028 (accessed on 28 September 2018).

27. Power, M.; Kirshner, J. Powering the state: The political geographies of electrification in Mozambique. Environ. Plan. C Politics Space 2018, 1-21. [CrossRef]

28. Baptista, I. 'We live on estimates': Everyday practices of prepaid electricity and the urban condition in Maputo, Mozambique. Int. J. Urban Reg. Res. 2015, 39, 1004-1019. [CrossRef]

29. Broto, V.C.; Baptista, I.; Kirshner, J.; Smith, S.; Alves, S.N. Energy justice and sustainability transitions in Mozambique. Appl. Energy 2018, 228, 645-655. [CrossRef]

30. Ahlborg, H.; Hammar, L. Drivers and barriers to rural electrification in Tanzania and Mozambique - grid extension, off-grid, and renewable energy technologies. Renew. Energy 2014, 61, 117-124. [CrossRef]

31. Cuamba, B.C.; Cipriano, A.; Turatsinze, R. Investment Incentives for Renewable Energy in Southern Africa: The Case of Mozambique. TKN, Maputo, 2013. Available online: https://www.iisd.org/pdf/ 2013/investment_\%20incentives_\%20mozambique.pdf (accessed on 22 November 2018).

32. Branco, J.P. Rural Electrification in Mozambique. National Institute of Standardization and Quality INNOQ, Maputo, 2012. Available online: http:/ / web.vdw.co.za/Portals/15/Documents/Presentations / Mozambique\%20-AFSEC\%2028Aug\%202012\%20Johannesburg.pdf (accessed on 27 November 2018).

33. Government of the Republic of Mozambique and Government of the Republic of Zimbabwe. A Part of the Project: Development of the Pungwe River Basin Joint Integrated Water Resources Management Strategy, a Monograph of the Pungwe River Basin, Light Edition. 2006. Available online: http://www. eisourcebook.org/cms/Feb\%202013/Pungwe\%20River\%20Basin,\%20IWRM\%20\&\%20ASM.pdf (accessed on 14 December 2018).

34. Wate, P. Baseline Study of the Energy Sources/Options and Planning in Manica and Sussundenga Districts of Manica Province. Mozambique, Maputo, 2007. Available online: https:/ / energypedia.info/ images/8/82/EN-Energising_the_millennium_development_goal...Pedro_Wate\%2C_et_.al..pdf (accessed on 5 September 2018). 
35. Tomei, J.; Gent, D. (Eds.) Equity and the Energy Trilemma: Delivering Sustainable Energy Access in Low-Income Communities; International Institute for Environment and Development: London, UK, 2015; Available online: http://gbpp.org/wp-content/uploads/2015/11/23112015.pdf (accessed on 5 September 2018).

36. Sebastião, A. O Modelo da Eletrificação de Moçambique: A Importância do Combate à Desflorestação no Meio Rural; Instituto Superior de Gestão (ISG): Lisbom, Spain, 2013; Available online: https:/ / comum.rcaap. pt/bitstream/10400.26/7133/1/Disserta\%C3\%A7\%C3\%A3o\%20_Ant\%C3\%B3nio_Sebasti\%C3\%A3o.pdf (accessed on 28 September 2018).

37. Trading Economics. Mozambique-Electric Power Consumption (kWh per Capita). Available online: https:/ / tradingeconomics.com/mozambique/electric-power-consumption-kwh-per-capita-wbdata.html (accessed on 8 December 2018).

38. Republic of Mozambique. Perfil do Distrito de Manica, Provincia de Manica. Available online: http:/ / www. ine.gov.mz/documentos/outros-documentos/perfil-do-distrito-de-manica-manica.pdf/view (accessed on 11 December 2018).

39. Bensch, G.; Peters, J.; Schraml, L. Energy Usage and Socio-Economic Conditions in Mozambique: Evidence from GTZ Electrification Project Regions. RWI Materialien 56, RWI-Leibniz-Institut für Wirtschaftsforschung. 2010. Available online: https://ideas.repec.org/p/zbw/rwimat/56.html (accessed on 11 December 2018).

40. Zana, C. Technical Appraisal for Micro Hydro Project Proposal in Chua Village, Manica District, Manica Province. A Project between GTZ-AMES and Kwaedza Simukai Manica. Deutsche Gesellschaft für Technische Zusammenarbeit (GTZ) GmbH, 2007. Available online: https: //energypedia.info/images/a/ae/EN_TECHNICAL_APPRAISAL_FOR_MICRO_HYDRO_PROJECT_ PROPOSAL_IN_CHUA_VILLAGE_MANICA_DISTRICT\%2C_MANICA_PROVINCE_Crispen_Zana.pdf (accessed on 11 December 2018).

41. freedominfo.org. Matrix Group International, Inc. Available online: http://www.freedominfo.org/regions / africa/mozambique/ (accessed on 8 December 2018).

42. Ritchie, J.; Lewis, J.; Nicholls, C.M.; Ormston, R. Qualitative Research Practice: A Guide for Social Science Students and Researchers; Sage: London, UK, 2013.

43. Bernhardt, J. The Effectiveness of Science-Policy Interactions: Case Studies on Climate Change Mitigation and Sustainable Development in Pan-European Forest Research and Politics. Ph.D. Thesis, University of Hamburg, Hamburg, Germany, 2015.

44. Peters, J.; Sievert, M. Impacts of rural electrification revisited-The African context. J. Dev. Eff. 2016, 8, 327-345. [CrossRef]

45. Heinrichs, H.; Laws, N. "Sustainability State" in the making? Institutionalization of sustainability in German federal policy making. Sustainability 2014, 6, 2623-2641. [CrossRef]

46. Nguyen-Trinh, H.A.; Ha-Duong, M. Perspective of $\mathrm{CO}_{2}$ capture \& storage (CCS) development in Vietnam: Results from expert interviews. Int. J. Greenh. Gas Control 2015, 37, 220-227.

47. Hugé, J.; Mukherjee, N.; Fertel, C.; Waaub, J.P.; Block, T.; Waas, T.; Dahdouh-Guebas, F. Conceptualizing the effectiveness of sustainability assessment in development cooperation. Sustainability 2015, 7, 5735-5751. [CrossRef]

48. Ilskog, E. Rural Electrification Sustainability Indicators-Manual for Field Workers. 2008. Available online: http:/ / swepub.kb.se/bib/swepub:oai:DiVA.org:kth-9132?tab2=abs\&language=en (accessed on 5 September 2018).

49. BHA. A Guide to UK Mini-Hydro Developments. The British Hydropower Association. 2012. Available online: http:/ /www.british-hydro.org/wp-content/uploads/2018/03/A-Guide-to-UK-minihydro-development-v3.pdf (accessed on 8 December 2018).

50. ESHA. Guide on How to Develop a Small Hydropower Plant. European Small Hydropower Association. 2004. Available online: https://energiatalgud.ee/img_auth.php/a/ab/Guide_on_How_to_Develop_a_ Small_Hydropower_Plant.pdf (accessed on 8 December 2018).

51. Koutsoyiannis, D. Scale of water resources development and sustainability: Small is beautiful, large is great. Hydrol. Sci. J. 2011, 56, 553-575. [CrossRef]

52. Kaunda, C.S.; Kimambo, C.Z.; Nielsen, T.K. Hydropower in the context of sustainable energy supply: A review of technologies and challenges. ISRN Renew. Energy 2012, 2012, 730631. [CrossRef] 
53. Public Private Infrastructure Advisory Facility (PPIAF). Mozambique: Private Sector Participation in the Energy Sector: Strategy Development Report. PPIAF-Funded Reports 1. 2003. Available online: http: / / www.ppiaf.org/page/knowledge-center/library (accessed on 25 January 2019).

54. Nhamire, B.; Mosca, J. Electricidade de Moçambique: Mau Serviço, não Transparente e Politizada. Centro de Integridade Pública Moçambique. 2014. Available online: https:/ / cipmoz.org/wp-content/uploads /2018/ 08/339_Relato\%CC\%81rio_Electricidade_de_Moc\%CC\%A7ambique.pdf (accessed on 11 September 2018).

55. UniZambeze \& Mining Development Fund. The Problems of Artisanal Gold Mining in Manica Province. 2012. Available online: https://cmsdata.iucn.org/downloads/gold_mining_in_mozambique.pdf (accessed on 14 December 2018).

56. Uamusse, M.M.; Tussupova, K.; Bengtsson, L.; Persson, K.M.; Berndtsson, R. Access to sustainable electrification: Possibilities for rural Mozambique. Unpublished manuscript in review. 2019.

57. Lahimer, A.A.; Alghoul, M.A.; Yousif, F.; Razykov, T.M.; Amin, N.; Sopian, K. Research and development aspects on decentralized electrification options for rural household. Renew. Sustain. Energy Rev. 2013, 24, 314-324. [CrossRef]

58. Andersson, L.; Samuelsson, P.; Kjellström, E. Assessment of climate change impact on water resources in the Pungwe river basin. Tellus A 2011, 63, 138-157. [CrossRef]

59. UNIDO \& ICSHP. World Small Hydropower Development Report, Eastern Africa, United Nations Industrial Development Organization (UNIDO) and International Center on Small Hydro Power (ICSHP). 2013. Available online: www.smallhydroworld.org (accessed on 14 December 2018).

(C) 2019 by the authors. Licensee MDPI, Basel, Switzerland. This article is an open access article distributed under the terms and conditions of the Creative Commons Attribution (CC BY) license (http://creativecommons.org/licenses/by/4.0/). 